Prepared in cooperation with the Stillaguamish Tribe of Indians

\title{
Contaminants of Emerging Concern in the Lower Stillaguamish River Basin, Washington, 2008-11
}

Open-File Report 2014-1028

Version 2.0, June 2016 



\section{Contaminants of Emerging Concern in the Lower Stillaguamish River Basin, Washington, 2008-11}

By Richard J. Wagner, Patrick W. Moran, Steven D. Zaugg, Jennifer M. Sevigny, and Jody M. Pope

Prepared in cooperation with the Stillaguamish Tribe of Indians

Open-File Report 2014-1028

Version 2.0, June 2016 


\title{
U.S. Department of the Interior SALLY JEWELL, Secretary
}

\section{U.S. Geological Survey Suzette M. Kimball, Director}

\author{
U.S. Geological Survey, Reston, Virginia: 2016
}

For more information on the USGS - the Federal source for science about the Earth, its natural and living resources, natural hazards, and the environment—visit http://www.usgs.gov or call 1-888-ASK-USGS.

For an overview of USGS information products, including maps, imagery, and publications, visit http://store.usgs.gov.

Any use of trade, firm, or product names is for descriptive purposes only and does not imply endorsement by the U.S. Government.

Although this information product, for the most part, is in the public domain, it also may contain copyrighted materials as noted in the text. Permission to reproduce copyrighted items must be secured from the copyright owner.

Suggested citation:

Wagner, R.J., Moran, P.W., Zaugg, S.D., Sevigny, J.M., and Pope, J.M., 2014, Contaminants of emerging concern in the lower Stillaguamish River Basin, Washington, 2008-11 (ver. 2.0, June 2016): U.S. Geological Survey Open-File Report 2014-1028, 14 p., http://dx.doi.org/10.3133/ofr20141028.

ISSN 2331-1258 (online) 


\section{Contents}

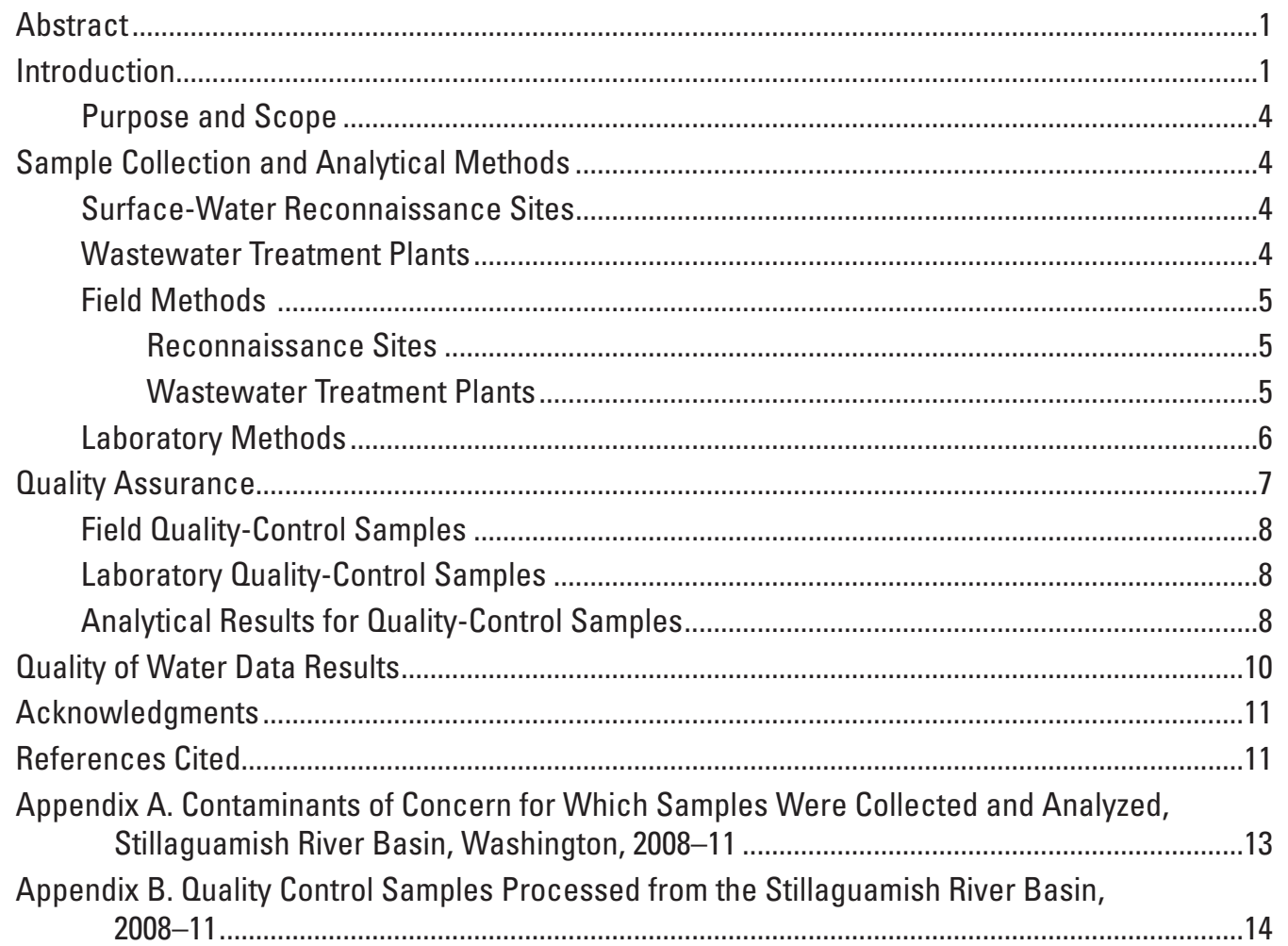

\section{Figures}

1. Map showing locations of water-quality sampling sites in the Stillaguamish River Basin, Washington 


\section{Tables}

1. Streams and wastewater treatment plant station numbers, station names, locations, and physical attributes of study sites sampled by the U.S. Geological Survey in the Stillaguamish River Basin, Washington, 2008-11

2. Physical properties in samples from streams in the Stillaguamish River Basin, Washington, September 2008

3. Concentrations of human-health pharmaceutical compounds analyzed by USGS National Water Quality Laboratory schedule 2080 in samples from streams in the Stillaguamish River Basin, Washington, September 2008

4. Concentrations of wastewater indicator compounds analyzed by USGS National Water Quality Laboratory schedule 1433 in samples from streams in the Stillaguamish River Basin, Washington, September 2008.

5. Concentrations of pharmaceutical compounds analyzed by USGS National Water Quality Laboratory custom method 8058 in samples from streams in the Stillaguamish River Basin, Washington, September 2008

6. Physical properties and concentrations of human-health pharmaceutical compounds analyzed by USGS National Water Quality Laboratory schedule 2080 in samples from influent and effluent of wastewater treatment plants in the lower Stillaguamish River Basin, Washington, 2009-11.

7. Concentrations of wastewater indicator compounds analyzed by USGS National Water Quality Laboratory schedule 1433 in samples from influent and effluent of wastewater treatment plants in the Stillaguamish River Basin, Washington, 2009-11

8. Concentrations of pharmaceutical and other organic compounds analyzed by USGS National Water Quality Laboratory custom methods 8058 and 8144 in samples from influent and effluent of selected wastewater treatment plants in the lower Stillaguamish River Basin, Washington, 2009-11

9. Concentrations of steroid hormones and related compounds analyzed by USGS National Water Quality Laboratory custom schedule 2434 in samples from effluent of selected wastewater treatment plants in the lower Stillaguamish River Basin, Washington, September 2010

10. Concentrations of halogenated organic compounds analyzed by USGS National Water Quality Laboratory custom method 8093 in solids and sediments from selected wastewater treatment plants in the lower Stillaguamish River Basin, Washington, 2009-11 


\section{Conversion Factors}

Inch/Pound to SI

\begin{tabular}{|c|c|c|}
\hline Multiply & By & To obtain \\
\hline \multicolumn{3}{|c|}{ Length } \\
\hline foot (ft) & 0.3048 & meter $(\mathrm{m})$ \\
\hline mile (mi) & 1.609 & kilometer (km) \\
\hline \multicolumn{3}{|l|}{ Area } \\
\hline square mile $\left(\mathrm{mi}^{2}\right)$ & 2.590 & square kilometer $\left(\mathrm{km}^{2}\right)$ \\
\hline \multicolumn{3}{|l|}{ Flow rate } \\
\hline cubic foot per second $\left(\mathrm{ft}^{3} / \mathrm{s}\right)$ & 0.02832 & cubic meter per second $\left(\mathrm{m}^{3} / \mathrm{s}\right)$ \\
\hline gallon per day (gal/d) & 0.003785 & cubic meter per day $\left(\mathrm{m}^{3} / \mathrm{d}\right)$ \\
\hline \multicolumn{3}{|l|}{ Pressure } \\
\hline pound per square inch (lb/in²) & 6.895 & kilopascal (kPa) \\
\hline
\end{tabular}

SI to Inch/Pound

\begin{tabular}{|c|c|c|}
\hline Multiply & By & To obtain \\
\hline \multicolumn{3}{|c|}{ Length } \\
\hline micrometer $(\mu \mathrm{m})$ & 0.00003937 & inch (in.) \\
\hline \multicolumn{3}{|c|}{ Volume } \\
\hline$\overline{l i t e r}(\mathrm{~L})$ & 0.2642 & gallon (gal) \\
\hline milliliter (mL) & 0.0002642 & gallon (gal) \\
\hline \multicolumn{3}{|c|}{ Mass } \\
\hline gram (g) & 0.03527 & ounce, avoirdupois (oz) \\
\hline kilogram (kg) & 2.205 & pound avoirdupois (lb) \\
\hline \multicolumn{3}{|c|}{ Pressure } \\
\hline kilopascal (kPa) & 0.1450 & pound per square inch $\left(\mathrm{lb} / \mathrm{ft}^{2}\right)$ \\
\hline
\end{tabular}

Temperature in degrees Celsius $\left({ }^{\circ} \mathrm{C}\right)$ may be converted to degrees Fahrenheit $\left({ }^{\circ} \mathrm{F}\right)$ as follows:

$$
{ }^{\circ} \mathrm{F}=\left(1.8 \times{ }^{\circ} \mathrm{C}\right)+32 .
$$

Concentrations of chemical constituents in water are given either in milligrams per liter $(\mathrm{mg} / \mathrm{L})$, which is approximately equal to parts per million, micrograms per liter $(\mu \mathrm{g} / \mathrm{L})$, which is approximately equal to parts per billion (ppb), or nanograms per liter, which is approximately equal to parts per trillion (ppt) Concentrations in solids or sediment are expressed in milligrams per kilogram, which is approximately equal to parts per million.

Specific conductance is given in microsiemens per centimeter at 25 degrees Celsius $(\mu \mathrm{S} / \mathrm{cm}$ at $\left.25^{\circ} \mathrm{C}\right)$. 


\section{Datums}

Vertical coordinate information is referenced to the North American Vertical Datum of 1988 (NAVD 88).

Horizontal coordinate information is referenced to the North American Datum of 1983 (NAD 83).

Altitude, as used in this report, refers to distance above the vertical datum.

\section{Abbreviations and Acronyms}

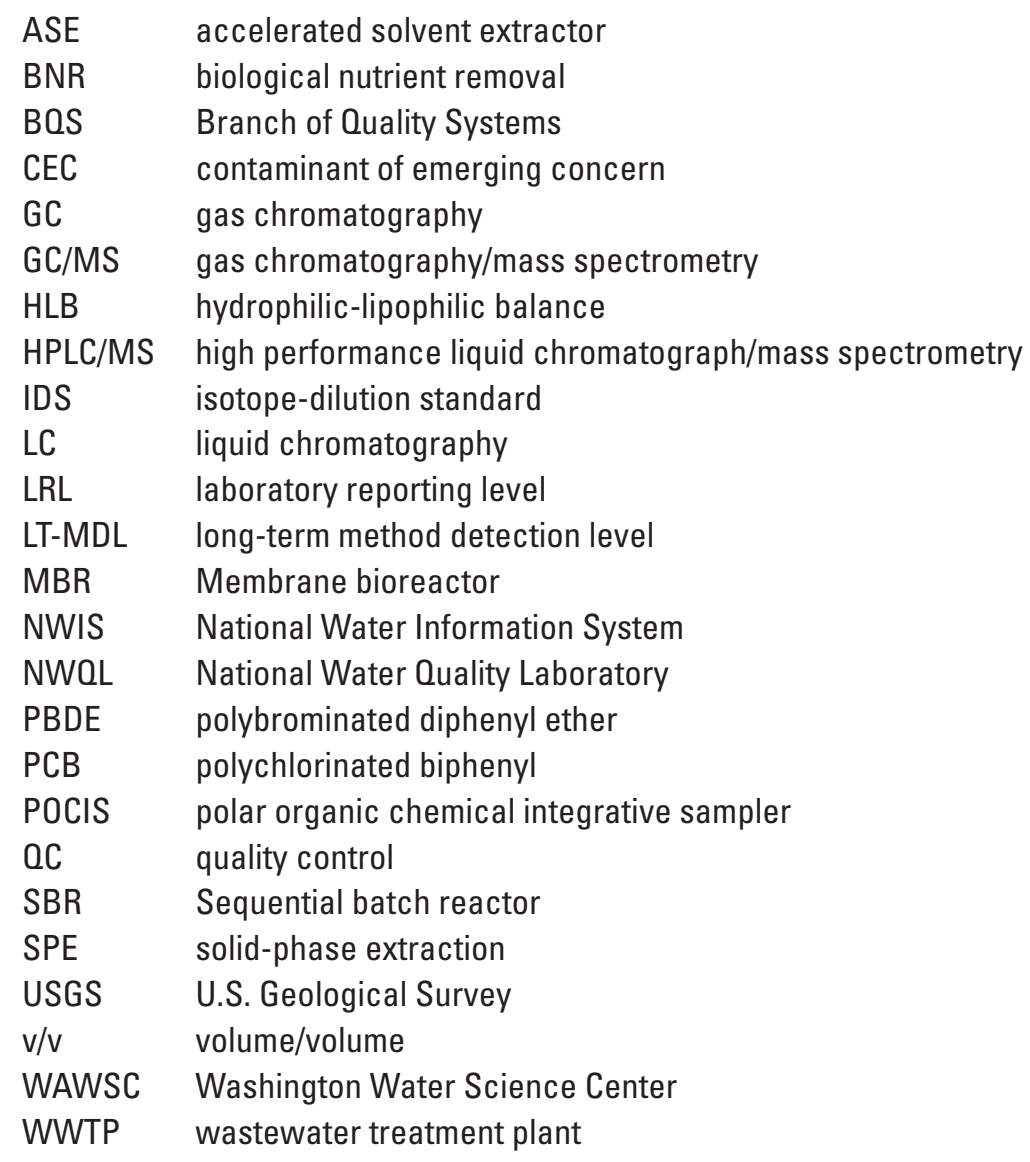




\title{
Contaminants of Emerging Concern in the Lower Stillaguamish River Basin, Washington, 2008-11
}

\author{
By Richard J. Wagner', Patrick W. Moran', Steven D. Zaugg', Jennifer M. Sevigny², and Jody M. Pope ${ }^{2}$
}

\begin{abstract}
A series of discrete water-quality samples were collected in the lower Stillaguamish River Basin near the city of Arlington, Washington, through a partnership with the Stillaguamish Tribe of Indians. These samples included surface waters of the Stillaguamish River, adjacent tributary streams, and paired inflow and outflow sampling at three wastewater treatment plants in the lower river basin. Chemical analysis of these samples focused on chemicals of emerging concern, including wastewater compounds, human-health pharmaceuticals, steroidal hormones, and halogenated organic compounds on solids and sediment. This report presents the methods used and data results from the chemical analysis of these samples.
\end{abstract}

\section{Introduction}

The U.S. Geological Survey (USGS), in cooperation with the Stillaguamish Tribe of Indians, collected samples from seven streams (fig. 1 and table 1) in the Stillaguamish River Basin, Washington, during September 2008 to determine if contaminants of emerging concern (CECs) were present in the surface waters of the basin. CECs are a group of chemical compounds that include selected human-health pharmaceuticals (appendix table A1), pharmaceutical and other compounds (appendix table A2), and wastewater indicator compounds (appendix table A3) that commonly include personal-care products, surfactants, industrial and household chemicals, and food additives. This initial survey of stream water at reconnaissance sites was followed in 2009, 2010, and 2011 with the collection of samples from wastewater treatment plants (WWTPs) in the lower basin. The analysis of CECs was expanded to include steroid hormones and related compounds hormones (appendix table A4), that are commonly found in treated wastewater effluent and surface waters that receive discharge from WWTPs, and halogenated organic compounds containing chloride, bromide, or iodide atoms (appendix table A5) such as polybrominated diphenyl ethers (PBDEs), chloro organic pesticides, and polychlorinated biphenyls (PCBs). All of these CECs are typically associated with WWTP effluent, on-site septic systems, urban runoff, and some animal production operations. The seven reconnaissance sites sampled in 2008 were selected on the basis of a gradient of susceptibility to contamination due to proximity to probable sources of CECs. Samples were collected in 2009-11 at three WWTPs where permission to sample was given and the samples were analyzed for concentrations of CECs.

No previous data provide a record to indicate the presence of CECs in the streams or water released from WWTPs within the Stillaguamish River Basin. There is evidence that, at sufficient concentration, these chemical compounds can impact the endocrine system of fish and wildlife, influencing hormonal and reproductive functions (U.S. Environmental Protection Agency, 1997; Pait and Nelson, 2002; and Wozniak and others, 2005). Additional water-quality sampling sites representative of various landuse activities in the basin were sampled in 2012 using a polar organic chemical integrative sampler (POCIS), a passive sampling technique, and fish tissue was also collected for analysis. The USGS will continue to sample sites in the Stillaguamish River Basin in a continuing effort to identify CECs in the watershed and investigate their potential biological effects on juvenile salmonids.

${ }^{1}$ U.S. Geological Survey.

${ }^{2}$ Stillaguamish Tribe of Indians. 


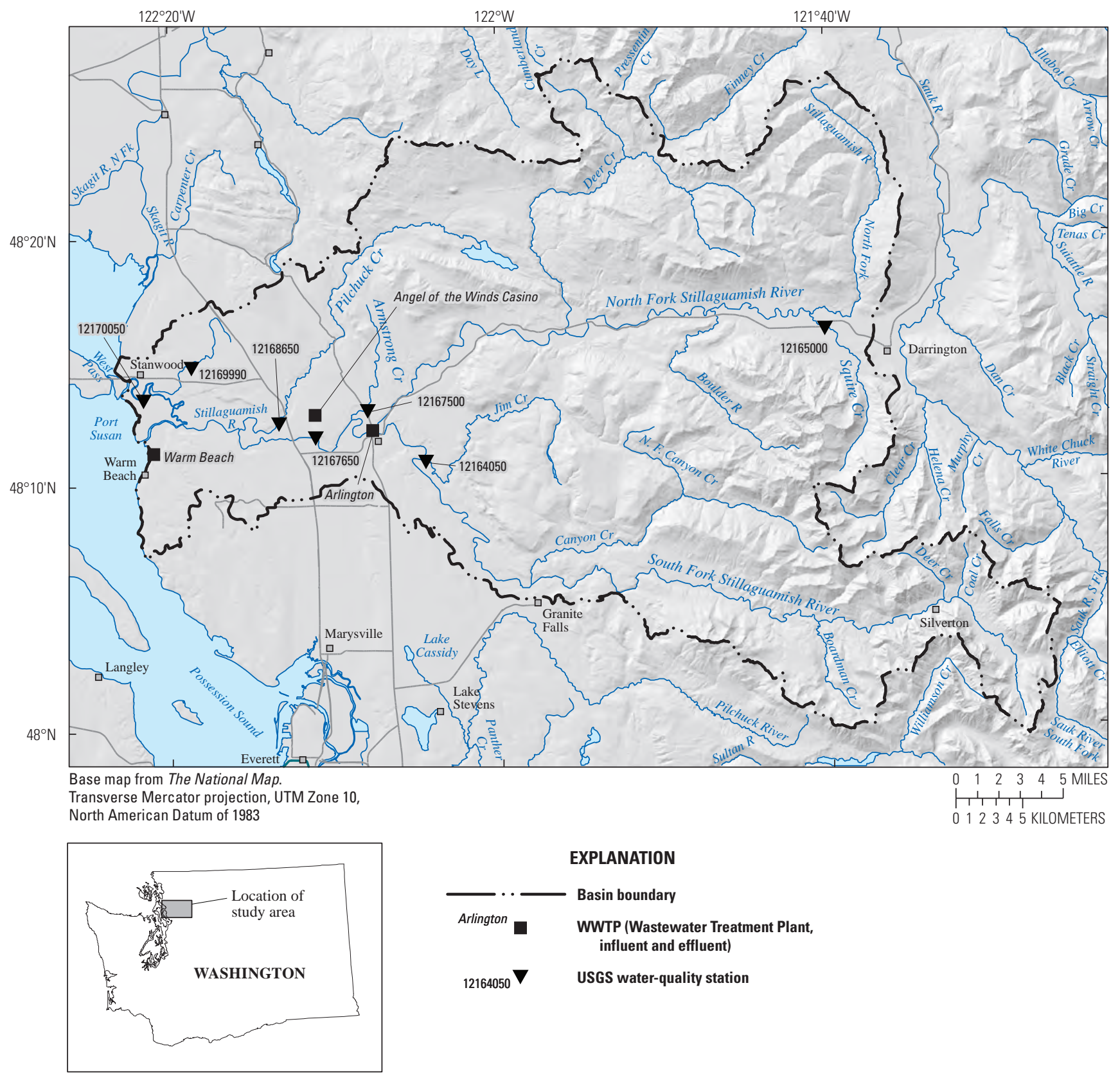

Figure 1. Locations of water-quality sampling sites in the Stillaguamish River Basin, Washington. Station names and descriptions are shown in table 1. 
Table 1. Streams and wastewater treatment plant station numbers, station names, locations, and physical attributes of study sites sampled by the U.S. Geological Survey in the Stillaguamish River Basin, Washington, 2008-11.

[Datums: NAVD 88, North American Vertical Datum of 1988; NAD 83 (horizontal datum), North American Datum of 1983. Altitudes are in feet above NAVD 88. A bbreviations: Ecology, Washington Department of Ecology; NOAA, National Oceanic and Atmospheric Administration; RM, river mile; USGS, U.S. Geological Survey; ft, foot; $\mathrm{mi}^{2}$, square mile; NA, not applicable]

\begin{tabular}{|c|c|c|c|c|c|c|c|c|c|}
\hline $\begin{array}{l}\text { USGS station } \\
\text { No. }\end{array}$ & $\begin{array}{l}\text { Ecology } \\
\text { or NOAA } \\
\text { station } \\
\text { identifier }\end{array}$ & $\begin{array}{l}\text { USGS station } \\
\text { name }\end{array}$ & Latitude & Longitude & $\begin{array}{l}\text { Altitude } \\
\text { (ft) }\end{array}$ & $\begin{array}{c}\text { Drainage } \\
\text { area } \\
\left(\mathrm{mi}^{2}\right)\end{array}$ & $\begin{array}{l}\text { Depth } \\
\text { (ft) }\end{array}$ & $\begin{array}{c}\text { Width } \\
\text { (ft) }\end{array}$ & Substrate \\
\hline \multicolumn{10}{|c|}{ Reconnaissance sites } \\
\hline 12164050 & 05G070 & $\begin{array}{l}\text { Jim Creek at Jordan Road near } \\
\text { Arlington }\end{array}$ & $48^{\circ} 11^{\prime} 02^{\prime \prime}$ & $122^{\circ} 04^{\prime} 36^{\prime \prime}$ & 104 & 47 & 30 & 3 & $\begin{array}{l}\text { Sand to } \\
\text { cobble }\end{array}$ \\
\hline 12167500 & 05E060 & $\begin{array}{l}\text { Armstrong Creek near } \\
\text { Arlington }\end{array}$ & $48^{\circ} 13^{\prime} 14^{\prime \prime}$ & $122^{\circ} 08^{\prime} 05^{\prime \prime}$ & 94 & 7.33 & 6 & 2 & $\begin{array}{c}\text { Sand and } \\
\text { gravel }\end{array}$ \\
\hline 12167650 & $\mathrm{ARL}^{1}$ & $\begin{array}{l}\text { Stillaguamish River at } \\
\text { RM } 12.2 \text { near Arlington }\end{array}$ & $48^{\circ} 11^{\prime} 54^{\prime \prime}$ & $122^{\circ} 11^{\prime} 15^{\prime \prime}$ & 34 & 538 & 150 & $4-5$ & $\begin{array}{l}\text { Sand to } \\
\text { cobble }\end{array}$ \\
\hline 12170050 & SPHW $^{1}$ & $\begin{array}{l}\text { Stillaguamish River near } \\
\text { Thule Road near Stanwood }\end{array}$ & $48^{\circ} 13^{\prime} 36^{\prime \prime}$ & $122^{\circ} 21^{\prime} 50^{\prime \prime}$ & 9 & 18 & 50 & $6-8$ & Silt, sand \\
\hline \multicolumn{10}{|c|}{ Wastewater treatment plants } \\
\hline 481119122210000 & NA & $\begin{array}{l}\text { Wastewater treatment plant influent } \\
\text { Warm Beach }\end{array}$ & t 48¹1'19" & $122^{\circ} 21^{\prime} 00^{\prime \prime}$ & 5 & NA & NA & NA & NA \\
\hline 481120122210400 & NA & $\begin{array}{l}\text { Wastewater treatment plant effluent } \\
\text { Warm Beach }\end{array}$ & t $48^{\circ} 11^{\prime} 20^{\prime \prime}$ & $122^{\circ} 21^{\prime} 04^{\prime \prime}$ & 5 & NA & NA & NA & NA \\
\hline 481201122074200 & NA & $\begin{array}{l}\text { Wastewater treatment plant influent } \\
\text { Arlington }\end{array}$ & t $48^{\circ} 12^{\prime} 01^{\prime \prime}$ & $122^{\circ} 07^{\prime} 42^{\prime \prime}$ & 64 & NA & NA & NA & NA \\
\hline
\end{tabular}

${ }^{1}$ NOAA site. 


\section{Purpose and Scope}

This report documents the results from chemical analyses of samples from streams, rivers, and WWTPs in the Stillaguamish River Basin from 2008 through 2011 during a multiyear project by the USGS in cooperation with the Stillaguamish Tribe of Indians and the city of Arlington. Some of the analytical methods were not approved as official methods of the USGS and were classified instead as research or custom methods. Data from unapproved methods cannot be made available through the USGS National Water Information System (Miller, 2004), which is the standard, publicly accessible data repository for results from official USGS methods. This report documents the original sampling results results, describes the laboratory analytical methods, provides a citable source for the original results, and provides public access to the results through online publication in this USGS report.

\section{Sample Collection and Analytical Methods}

Surface water was collected by the USGS and the Stillaguamish Tribe of Indians from seven reconnaissance sites within the Stillaguamish River Basin from September 23 through September 30, 2008 (fig. 1). Water from the influent and effluent of three WWTPs was sampled from 2009 through 2011. Samples of influent and effluent were collected at WWTPs from the city of Arlington in 2009 and 2011, from the Warm Beach community in 2010, and from the Angel of the Winds Casino in 2010 and 2011 (appendix table A6).

\section{Surface-Water Reconnaissance Sites}

Seven sites at streams or rivers considered susceptible to contamination due to their proximity to CEC sources (fig. 1 and table 1) were sampled from September 23 through September 30, 2008. Sites included Jim Creek at Jordan Road (station number 12164050) near the confluence of the South Fork Stillaguamish River, which was approximately $30 \mathrm{ft}$ wide and $3 \mathrm{ft}$ deep at midstream with moderate flow at the time of sampling. The channel bottom was composed of sand to cobble-sized rocks with heavy vegetation growth on both banks. Squire Creek (station number 12165000), considered a reference site, drains a U.S. Forest Service wilderness area and Department of Natural Resources forest lands, is located at the Squire Creek Campground, just upstream of its confluence with the North Fork Stillaguamish River. At the time of sampling, the channel was approximately $30 \mathrm{ft}$ wide and $2 \mathrm{ft}$ deep at midstream, with slow to moderate current. The creek bottom was composed of sand to cobble-sized rocks, and vegetation had grown to the edge of the water. Armstrong
Creek below the intake of the Harvey Creek Hatchery (station number 12167500) was approximately $6 \mathrm{ft}$ wide and $2 \mathrm{ft}$ deep, and the streambed was composed of sand and gravel. The Stillaguamish River (station number 12167650), about 1 mi downstream of the Arlington WWTP outfall, was approximately $150 \mathrm{ft}$ wide and 4-5 ft deep at midstream with moderate flow during the period of sampling. The river bottom was composed of sand to cobble-sized rocks. Pilchuck Creek at lower Pilchuck Park (station number 12168650) is a large tributary that flows through rural land with timber production, agricultural uses, and dairies before entering into the Stillaguamish River. The river channel was approximately $70 \mathrm{ft}$ wide and $3 \mathrm{ft}$ deep at midstream with low to moderate flow. The streambed was composed of sand to cobble-sized rocks, and heavy vegetation had grown to the edge of the water. Church Creek at Jensen Bridge (station number 12169990) is a small tributary to the Stillaguamish that flows through the suburban and rural areas of the city of Stanwood. The narrow channel was approximately $8 \mathrm{ft}$ wide and $1 \mathrm{ft}$ deep at midstream. The streambanks consisted of heavy riparian vegetation, and the channel bottom was composed of gravel and boulders. The Stillaguamish River near Stanwood (station number 12170050), downstream of the Stanwood WWTP outfall, is on the Stillaguamish River near Irvine Slough and is often locally referred to as the "old main stem Stillaguamish". The tidally influenced channel was approximately $50 \mathrm{ft}$ wide and 6-8 $\mathrm{ft}$ deep at midstream with slow to moderate current, and the channel bottom consisted of silt and sand. The site was sampled during the maximum of an outgoing tide to ensure the sample was not influenced by tidal inflow from Port Susan.

\section{Wastewater Treatment Plants}

Currently, all three WWTPs are tertiary treatment plants. The facilities for the city of Arlington and Angel of the Winds Casino use screening and primary treatment (settling), followed by secondary treatment with activated sludge, and followed by membrane bioreactors (MBR) prior to disinfection and discharge. The Warm Beach community WWTP does not use the activated sludge or MBR steps; effluent is transferred to a pair of lagoons, passed to a constructed wetland, and filtered again prior to release into Puget Sound. The Angel of the Winds WWTP effluent is released to groundwater infiltration by passing through a lagoon to an infiltration gallery. The Arlington WWTP releases effluent to the Stillaguamish River; the plant was upgraded to tertiary treatment with the installation of an MBR and biological nutrient removal (BNR) system prior to sampling in 2011.

Samples were collected from the WWTP for Arlington, in Snohomish County, in 2009 and again in 2011 after a major upgrade to the processing facilities. Treated effluent from Arlington is released midstream in the Stillaguamish River. The WWTP at Warm Beach serves the Warm Beach Christian 
Camp, retirement center, mobile home park, and community center, and is part of the unincorporated community of Warm Beach near Stanwood, Washington. Treated effluent is released to Port Susan after spending time in holding lagoons. Samples of the influent and effluent were collected in 2010. Angel of the Winds Casino is located several miles northwest of Arlington, Washington. Samples of the influent and effluent were collected in 2010, but some of the sample bottles were broken in transit and the sampling was repeated in 2011.

Samples were first collected from the Arlington WWTP in August 2009 when it operated as a sequential batch reactor (SBR) with ultraviolet disinfection at a rate of about 1 million gallons per day. At the time, the city's population of 17,711 was served in part through 4,347 sewer connections, including 93 percent residential connections and 7 percent commercial or industrial. Weather during the time of sample collection was generally warm and dry, and infiltration and inflow were not affecting influent characteristics. Influent was sampled at the headworks and effluent was sampled downstream of all treatment at the inlet to the discharge pipe, which stretches to an outfall diffuser in the thalweg of the Stillaguamish River. The WWTP had undergone significant expansion and upgrade to a water reclamation facility prior to sampling in September 2011. The population served had increased slightly to 17,930 , and service of the same residential-commercial distribution had increased to 4,427 sewer connections. Again, infiltration and inflow were not affecting influent characteristics. The upgrade incorporates microfiltration through membrane bioreactors, biological nutrient removal, and improved ultraviolet disinfection to produce effluent of Class A reclaimed water quality. Sample and outfall locations did not change significantly with the upgrade.

The Warm Beach WWTP is part of the unincorporated community of Warm Beach near Stanwood, Washington. It serves a permanent population and a transient population of about 800 through approximately 350 connections, including the Warm Beach Christian Camp, retirement center, mobile home park, and community center. At the time of sampling in September 2010, the WWTP treated about 35,000 gallons per day of effluent, with effluent transferred to a series of constructed holding lagoons prior to release to Port Susan on Puget Sound.

The Angel of the Winds WWTP serves the Angel of the Winds Casino operated by the Stillaguamish Tribe of Indians in a rural area several miles northwest of Arlington. On-site facilities include the casino, restaurants, offices, and a fueling facility. The average daily customer base served was about 3,600 customers per day during 2010 and 2011. Samples of the influent and effluent were collected in September 2010, but some of the sample bottles were broken in transit and the sampling was repeated in September 2011. At the time of sampling in September 2010, the WWTP treated about 18,000 gallons per day of effluent. Effluent from the Angel of the Winds WWTP is released to groundwater infiltration by passing through a lagoon that drains to a subsurface infiltration gallery.

\section{Field Methods}

Water temperature, $\mathrm{pH}$, specific conductance, and dissolved oxygen were measured at each site when possible, following the methods described by Wilde (variously dated) and by Gibs and others (2007) using a YSI 600 XLM sonde or standard field monitoring meters and probes calibrated to manufacturer's specifications. Locations and associated measurements are listed in table 2. Streamflow for the reconnaissance sites are from the Washington Department of Ecology streamgages in the watershed (Washington State Department of Ecology, 2013; National Atmospheric Oceanic Administration, 2013). Quality control (QC) samples were also processed during collection of surface water samples at sites in 2008 and for WWTP samples in 2009-11. Quality control (QC) samples were also processed during collection of surface water samples at sites in 2008 and for WWTP samples in 2009-11, as part of an overall project quality assurance (QA) plan following the procedures described by Wagner and others (1997).

\section{Reconnaissance Sites}

Stream-water samples were collected with a handheld, depth-integrating sampler equipped with a Teflon nozzle and 1-liter Teflon ${ }^{\circledast}$ bottles, as described by the U.S. Geological Survey (2006). Depth-integrated samples were collected at a minimum of 10 equal intervals across the stream and composited in a 14-liter Teflon churn splitter. These composite samples were mixed in the churn and subsamples were filtered through a 0.7 micrometer glass-fiber filter into organic-free glass bottles for subsequent analysis. Specific conductance and $\mathrm{pH}$ were measured on aliquots of water from the churn, and water temperature and dissolved oxygen were measured at the centroid of the stream. Water samples were shipped overnight to the USGS National Water Quality Laboratory (NWQL) in Lakewood, Colorado, for analysis of human-health pharmaceuticals by NWQL schedule 2080; pharmaceutical and other compounds by NWQL custom method 8058; and wastewater compounds were analyzed by NWQL schedule 1433. A complete list of parameters analyzed in these samples is provided in appendix tables A1, A2, and A3.

\section{Wastewater Treatment Plants}

Four samples of effluent and influent were collected at each of the WWTPs during 24 hours and the effluent and influent samples were composited in separate Teflon churns. Subsamples were filtered through a 0.7 micrometer glass-fiber filter and submitted to the NWQL for analyses of waste-indicator chemicals, pesticides, and human-health pharmaceuticals. In 2010, samples also were submitted for analysis of steroid hormones and related compounds using NWQL custom method 2434. Solids filtered from influent and effluent samples collected during 2009 were saved on the glass-fiber filters and submitted to the NWQL for analysis of 
halogenated organic compounds in sediment; the analyses were completed using NWQL custom method 8093. The solids from only influent samples collected during 2010 and 2011 were saved on the glass-fiber filters and submitted to the NWQL for analysis of halogenated organic compounds. All processed subsamples were stored on ice and shipped directly to the laboratory on the day of collection. A complete list of parameters analyzed by NWQL custom method 2434 and custom method 8093 is provided in appendix tables A4 and $\mathrm{A} 5$.

\section{Laboratory Methods}

Samples were analyzed for human-health pharmaceutical compounds using NWQL schedule 2080; for wastewater compounds using NWQL schedule 1433; for steroid hormones and related compounds using NWQL custom method 2434; for halogenated organic compounds in solids using NWQL custom method 8093; and additional pharmaceuticals and organic compounds by methods 8058 and 8144 . Samples for analysis of human-health pharmaceuticals were extracted at the NWQL using a modified styrene-divinylbenzene resin-based solid phase cartridge and analyzed using a highperformance liquid chromatography/mass spectrometry system, as described by Furlong and others (2008). In addition, pharmaceutical compounds also were analyzed by custom methods (HPLC/MS) that are modifications to the method described by Zaugg and others (2006) as further described by Phillips and others (2010) and Zaugg and others (2014). During the time of the project, the analysis of pharmaceutical compounds using research methods analyzed by gas chromatography/mass spectrometry (GC/MS) expanded from the eight original compounds to 48 that were analyzed in 2011; which was subsequently expanded to include some pharmaceuticals and is now known as NWQL method 8144 by Zaugg and others 2014. The method, using these modifications, has not been completely evaluated by the USGS, and no publication can be cited at this time that describes the custom method used. Hence, the results for these eight compounds are for screening purposes only and are not available from the National Water Information System (NWIS) database.

Samples for analysis of wastewater compounds (NWQL schedule 1433) were extracted by vacuum through polystyrene-divinylbenzene cartridges, eluted, and then analyzed by capillary-column GC/MS, as described by Zaugg and others (2006). To check for sample matrix effects and laboratory extraction efficiency, a standard spike solution is added to each sample. This spike solution is prepared and provided by NWQL. In addition to this standard spike solution, additional human-health pharmaceutical compounds were added to the spiking compound for use in schedule 1433 and analyzed using the same methodology and data-quality objectives. Because these additional compounds had not been formally approved by the USGS at the time of collection, those data are for screening purposes only and are not approved for storage in NWISWeb.

Samples for analysis of steroid hormones and related compounds by NWQL custom method 2434 were determined by using an isotope-dilution quantification procedure. Method 2434 automatically applies a correction for procedural losses in the reported analyte concentration based on the absolute recovery of deuterium- or carbon-13-labeled isotopedilution standard (IDS) compounds that are added to a sample just prior to extraction. The IDS compounds are either exact or structurally similar isotopic analogs of the method analytes, which makes them suitable for recovery correction of the quantified analyte result. This custom method was subsequently approved in 2012 and is similar to the method described by Foreman and others (2012), but because the method had not been formally approved by the USGS at the time of sampling and analysis, the data are for screening purposes only and are not approved for storage in NWISWeb.

Halogenated organic compounds in sediment were determined by analyzing the solids filtered from influent samples on the glass-fiber filters using NWQL custom method 8093. The filter papers and sample were loaded into 22-milliliter stainless steel cells and extracted twice using an accelerated solvent extractor (ASE), the ASE200 (Dionex Corp., Sunnyvale, California) at a pressure of 13,800 kPa (2,000 pounds per square inch) with a percent volume/volume $(\mathrm{v} / \mathrm{v})$ mixture of water to isopropyl alcohol $(20: 80, \mathrm{v} / \mathrm{v})$ at $80^{\circ} \mathrm{C}$ and water to isopropyl alcohol $(20: 80, \mathrm{v} / \mathrm{v})$ at $200^{\circ} \mathrm{C}$ for 40 minutes at each temperature. A 0.5-gram aminopropyl solid-phase extraction (SPE) cartridge is placed above an Oasis (Waters Corp., Milford, Massachusetts) hydrophiliclipophilic balance (HLB) 1-gram SPE cartridge to isolate the compounds from the ASE extract. The SPE cartridges are dried with nitrogen gas, and adsorbed compounds are eluted with dichloromethane-diethyl ether $(4: 1, \mathrm{v} / \mathrm{v})$. The extract is concentrated to 0.5 milliliters that is added to 2 grams of Florisil that is eluted with 5 milliliters of hexane, followed by a mixture of pentane:acetone $(94: 6, \mathrm{v} / \mathrm{v})$ to remove some compounds that are more polar than the target method analytes. The extract is concentrated to 1 milliliter; an internal standard (PCB-209- ${ }^{13} \mathrm{C}_{12}$ ) is added to the extract and then analyzed using an Agilent Technologies Model 5975 capillary-column gas chromatograph/mass spectrometer with the mass spectrometer operated in the electron capture negative ion mode using ammonia reagent gas. Compounds are identified by selected ion monitoring.

All reported compounds had to meet qualitative identification criteria based on matching of retention times plus or minus ( \pm ) 0.05 minutes and ion ratios ( \pm 30 percent) determined from analysis of authentic standards. Quantification was then accomplished using a nine-point calibration curve (0.2, 0.5, 1, 2, 5, 10, 20, 50, 100 nanograms) and the internal standard method using PCB-209- ${ }^{13} \mathrm{C}_{12}$. Three 
surrogate compounds were added to each sample prior to extraction to monitor the effectiveness of the extraction process. A surrogate compound is not expected to be found in any environmental sample and is added to every sample in a known amount prior to sample processing. The surrogate is used to monitor method performance for each sample. Because this analytical method had not been completely evaluated by the USGS at the time of sample collection and analysis, the results are categorized as using a research method and are for screening purposes only; the results therefore are not available through NWISWeb. Although these methods are not approved, all results from associated field and laboratory quality-control samples are acceptable, and the quality of the data analyzed by these research methods is acceptable.

\section{Quality Assurance}

All field activities for the collection of water-quality samples and water-quality monitoring follow the general guidelines and procedures described in the USGS Washington Water Science Center (WAWSC) Quality Assurance Plan, as described by Wagner and others (2007). Quality control (QC) samples for analyses of CECs (waste-water indicator compounds, human health pharmaceuticals, steroid hormones, and related compounds) were prepared at the study sites, in addition to the usual maintenance and calibrations of water-quality instruments and onsite documentation of field conditions and processing, to identify and quantify the bias and variability that may have occurred during the collection, processing, and analysis of samples. Bias is defined as systematic error that is manifested as a consistent positive or negative deviation from the known or true value and variability is defined as random error; bias and variability in field or laboratory procedures can be identified by processing QC samples (U.S. Geological Survey, 2006). The field QC samples utilized during this project included: (1) field blanks to evaluate if any positive bias to constituent concentrations was introduced during collection and handling of equipment and sample water; (2) field and laboratory matrix spikes to evaluate positive or negative matrix effects on concentrations of organic compounds; and (3) replicates to assess total variability in the data due to collection, handling, and laboratory analytical methods.

Samples from seven surface-water reconnaissance sites and three WWTPs were submitted to the NWQL for analysis of a total of 78 laboratory analytical procedures. Twenty eight of these laboratory procedures were QC samples (appendix table B1) and 50 of the laboratory procedures were environmental samples, resulting in a proportion of QC sample types to total number of samples collected of 35.9 percent.

In addition to the field quality assurance, all samples submitted to the NWQL are subject to internal laboratory quality assurance under a Quality Assurance Plan described by Maloney (2005), Stevenson (Quality Management System, U.S. Geological Survey National Water Quality Laboratory, written commun., May 2013), and Stevenson and Barnard (U.S. Geological Survey National Water Quality Laboratory Quality Assurance and Quality Control, written commun., March 2013). All samples submitted to the NWQL for analysis during this study were accompanied with several types of laboratory QC samples, including the usual internal calibration standards and internal surrogates described by the method documentation and laboratory reagent blanks and laboratory reagent spikes as described in the following section, "Laboratory Quality-Control Samples."

Seven QC samples were processed for laboratory analytical procedures at the reconnaissance sites in 2008 and 21 QC samples were processed at the WWTPs from 2009 to 2011 (appendix table B1). Four field blanks were processed-one during each sampling period: one during the week of sampling at reconnaissance sites in 2008, and one during each sampling period of WWTPs in 2009, 2010, and 2011. Field blanks were prepared for analysis of human-health pharmaceuticals (NWQL schedule 2080) and wastewater indicators (NWQL Schedule 1433) and pharmaceuticals by NWQL custom methods 8058 or 8144 (appendix tables A1, A3, and A2, respectively) also were processed in 2008, 2009, 2010, and 2011. Additional field blanks were prepared in 2010 for analysis of steroid hormones and related compounds by NWQL Schedule 2434 (appendix table A4). Five field matrix spikes were processed for analysis of NWQL schedule 1433 (two in 2008 and one each in 2009, 2010, and 2011). Six samples were submitted to the NWQL for laboratory matrix spiking and analysis of NWQL schedules 2080 and 2434 (one NWQL schedule 2080 laboratory matrix spike in 2008, one in 2009, 2010, and 2011; and two NWQL schedule 2434 laboratory matrix spikes in 2010). Four replicate samples were submitted for analysis between 2008 and 2011. One field replicate from the surface-water reconnaissance sites was submitted to the NWQL in 2008 for analysis of human health pharmaceuticals by NWQL schedule 2080 and three WWTP effluent replicates pairs were submitted between 2009 and 2011 for analysis of pharmaceuticals and other organic compounds by NWQL custom method 8058 or 8144 . In addition to split-sample field replicates that were analyzed by the same laboratory analytical methods, six CEC compounds were analyzed by two analytical methods. These latter samples are not true replicates but do provide a measure of intra-method variability. In instances where multiple methods are used to analyze chemical compounds, the NWQL uses a hierarchical process to identify a "preferred" method for storage of one value for a parameter code/method code in the USGS NWIS database. A gas chromatography (GC) method will generally be preferred over a liquid chromatography (LC) method, but common analyte performance by each analytical technique is reviewed periodically and in some cases, a high performance liquid chromatography/mass spectrometry (HPLC/MS) method may be preferred over a GC/MS method for a specific analyte. 
Reporting levels during this study varied but were based on the concepts presented by Oblinger Childress and others (1999), in which a long-term detection level (LT-MDL) was derived by determining the standard deviation (or F-pseudosigma) of a minimum of 24 spike-sample measurements near the LT-MDL over an extended period (preferably at least 6 months). The LT-MDL data controls false positive error (reporting detection when a sample contained no analyte) and are collected continuously to assess year-toyear variations in the LT-MDL. A Laboratory Reporting Limit $(\mathrm{LRL})$ is the less-than $(<)$ value reported by the NWQL when nothing is detected and controls false negative error. The LRL generally is set at twice the LT-MDL for organic analyses at the NWQL. The probability of falsely reporting no detection for a sample that contained an analyte at a concentration equal to or greater than the LRL is predicted to be no more than 1 percent. Because these LT-MDLs and LRLs are reevaluated annually, on the basis of the most current quality-control data, they are subject change.

\section{Field Quality-Control Samples}

Field-blank samples were subjected to the same conditions and handling as the environmental samples and were prepared onsite with reagent-grade water prior to the collection of environmental sample water. Field blanks for CECs were prepared with organic-free water certified for use for organic constituents. Typically, the same set of equipment used in processing field blanks was used for collecting the environmental water samples. The handling and preparation of equipment for field blank collection and processing followed the guidelines in the USGS National Field Manual (U.S. Geological Survey, 2006). Field matrix-spike samples were split-replicate samples consisting of multiple 1-L glass bottles filtered from the churn splitter into clean 1-L glass bottles and shipped on ice to the NWQL for chemical analyses. The field matrix-spike bottles of filtered water to be analyzed for wastewater indicator chemicals were spiked in the field with $0.1 \mathrm{~mL}$ of a spike solution containing a mix of target analytes in known concentrations (for NWQL schedule 1433), as described by U.S. Geological Survey (2006). Bottles of filtered water for analysis of human-health pharmaceuticals (by NWQL schedule 2080) and for analysis of steroid hormones and related compounds (by NWQL schedule 2434) were shipped on ice to the NWQL and spiked in the laboratory with a $0.1 \mathrm{~mL}$ spike solution containing a mixture of target analytes in known concentrations.

\section{Laboratory Quality-Control Samples}

In addition to quality-assurance procedures used in the field, the NWQL also follows general guidelines and procedures to ensure quality work procedures and results as described by Maloney (2005). The NWQL routinely follows standard operating procedures for the analysis of all constituents; follows accepted procedures for instrument calibration; and utilizes instrument blanks, laboratory replicates, and continuing calibration verification standards to ensure the quality of analyzed data. Internal QC samples are a part of each sample batch, where no more than 20 environmental samples are prepared and analyzed at one time with the same method, personnel, and reagent lots. A minimum of one method (or set) laboratory blank, and one laboratory reagent spike, and a minimum of one surrogate (a compound that is similar in physical and chemical properties but do not normally occur in the environment because they are typically isotopically labeled, fluorinated, or brominated) is analyzed with each sample batch. These internal qualitycontrol procedures are augmented by analysis of samples in several external standard reference programs, such as participation by the NWQL in the USGS Branch of Quality Systems (BQS) NWQL Blind Blank Program, Inorganic Blind Sample program, and the Organic Blind Blank program, as described on the USGS BQS website at http://bqs.usgs.gov. Results from these internal quality-control procedures indicate the NWQL data quality to be within acceptable limits during the period of this study, 2008-11.

\section{Analytical Results for Quality-Control Samples}

Field blanks were processed for each sampling period and submitted to the NWQL for analysis of NWQL schedules 1433 and 2080 in addition to NWQL custom method 8058 during 2008 and 2009 and custom method 8144 during 2010 and 2011 (tables 3-10; appendix table B2). A total of eight organic compounds were detected in the four field-blank samples collected from 2008 through 2011. Albuterol was the only compound detected in the field blank sample processed during 2008, but there were no detections of albuterol in any of the environmental samples collected during 2008. The field blank processed during 2009 at the Arlington WWTP contained detections of four organic compounds - camphor, benzophenone, phenanthrene, and $\mathrm{N}, \mathrm{N}$-diethyl-m-toluamide (DEET), all at concentrations that were less than the LRL. Three of the compounds (camphor, benzophenone, and DEET) also were detected in the influent and effluent samples of the Arlington WWTP. Phenanthrene was detected only in the sample of the influent of the Arlington WWTP. All of the detections in the field blank, except for benzophenone and camphor, were 5 to 10 times less than the LRL and do not appear to indicate any bias in the environmental samples. However, the detection of camphor in the field blank effluent may indicate a small positive bias in the environmental samples. The field blank processed in 2010 at the Angel of the Winds Casino WWTP contained detections of five organic compounds-camphor, benzophenone, isophorone, menthol, and hexahydrohexamethyl cyclopentabenzopyran (HHCB). All detections of organic compounds in the field blank were less than the LRL, except for the detection of benzophenone. The concentration of camphor in the field 
blank was less than the LRL and greater than the LT-MDL. The concentration of benzophenone in the field blank during 2010 was greater than the LRL. The concentrations of organic compounds in environmental samples collected and processed in 2010 that correspond to those detected in the field blank processed during 2010 were generally less than the LT-MDL; benzophenone and isophorone were detected at concentrations near the LT-MDL in samples from the effluent of the Warm Beach WWTP. HHCB was detected at concentrations near the LT-MDL in samples from the effluent of the Angel of the Winds Casino WWTP. In the corresponding environmental samples, the concentration of benzophenone in the Warm Beach concentrations of benzophenone in the Warm Beach influent in 2010 were 20 times the concentration of the field blank and the concentrations of HHCB were more than 50 times the concentration of the field blank. The sample bottle for the Angel of the Winds Casino WWTP influent was broken in transit. The sample from the influent of the Warm Beach WWTP had detections of all organic compounds detected in the field blank except for isophorone, which was reported as less than $0.91 \mathrm{ug} / \mathrm{L}$ (a raised reporting limit that is more than 10 times the normal LT-MDL because of the reduced sample volume as well as the difficult analytical sample matrix). The field blank processed during 2011 at the Arlington WWTP contained no detections of organic compounds, suggesting no positive bias in any of the associated environmental samples during 2011.

Five field matrix spikes for analysis of NWQL schedule 1433were submitted to the NWQL for analysis between 2008 and 2011. Two samples were field matrices of stream water from two reconnaissance sites and three were field matrices from WWTP effluent (appendix table B3). Two spike solution lots were used for analysis of NWQL schedule 1433 from 2008 to 2011 and both contained all of the analytes of interest for this laboratory NWQL schedule. Only a few of the compounds in samples from the surface-water reconnaissance sites were detected at a level that provided a sufficient environmental background concentration to calculate matrixspike recoveries; but numerous compounds were detected in the environmental samples from the WWTP effluent, usually at small concentrations at or near the limit of detection. All other recoveries were calculated with background sample values reported as less than the laboratory reporting level and shown as ranges of spike recovery that were calculated using zero for the lowest possible environmental background concentration and the laboratory reporting level as the highest possible environmental background concentration.

Six samples were submitted to the NWQL for subsequent spiking in the laboratory between 2009 and 2011 (appendix table B4). One sample from a surface-water reconnaissance site and three samples from WWTP effluent were submitted to the NWQL and spiked with a spike solution containing a mixture of target analytes in known concentrations for analysis of human-health pharmaceuticals by schedule 2080, and two samples of WWTP effluent were submitted 2010 and spiked with a spike solution containing a mixture of target analytes in known concentrations for analysis of steroidal hormones and other organic compounds by NWQL schedule 2434. None of the human-health pharmaceutical compounds in the sample from the surfacewater reconnaissance sites were detected at a level that provided a sufficient environmental background concentration to calculate matrix-spike recoveries; but several compounds were detected in the environmental samples from the WWTP effluent, usually in small concentrations at or near the limit of detection. As with the field matrix spikes, recoveries for laboratory matrix spikes with background sample values reported as less than the laboratory reporting level were calculated as ranges of spike recovery that were calculated using zero for the lowest possible environmental background concentration and the laboratory reporting level as the highest possible environmental background concentration.

The NWQL suggests default acceptance criteria of 60-140 percent for recoveries of organic field matrix spike samples (D.L. Stevenson and A.R. Barnard, U.S. Geological Survey National Water Quality Laboratory Quality Assurance and Quality Control, written comm., March 2013). For samples with ranges of spike recovery, the highest recovery value was used to evaluate if recovery was less than the acceptance criteria of 60 percent; and the lowest recovery value was used to evaluate if recovery was greater than the acceptance criteria of 140 percent. The International Union of Pure and Applied Chemistry (2014) define matrix effects as "the combined effect of all components of the sample other than the analyte on the measurement of the quantity;" and, "if a specific component can be identified as causing this, it is referred to as interference." Because of the matrix effects in complex mixtures of WWTP samples, it is not surprising to encounter problems with analytical procedures and recoveries that are often less than ideal. Percent recoveries for samples submitted for analysis of NWQL schedule 1433 from 2008 to 2011 were generally within these acceptance criteria, with several exceptions (appendix table B5). Shoemaker and Bassett (2005) also suggest that recoveries for analysis of organic compounds should be between 60-140 percent, except for low-level fortification near or at the level of detection, where 50-150 percent recoveries are acceptable. For recoveries outside these criteria, the analysis is judged to be matrix biased. A total of 20 organic compounds analyzed for NWQL schedule 1433 did not meet these acceptance criteria at least once during the sampling period between 2008 and 2011. Percent recoveries for three organic compounds (tetrachlorethene, d-limonene, and 3-tert butyl-4-hydroxyanisole [BHA]) did not meet these default acceptance criteria for any of the five field matrix spikes. The organic compound 2,6-dimethylnaphthalene did not meet this acceptance criteria for four of the five matrix spikes; diazinon did not meet this acceptance criteria in three of the five matrix spikes; and indole and 4-n-octylphenol did not meet this acceptance criteria for two of the five matrix spikes. 
An additional 13 organic compounds did not meet these acceptance criteria for one of the five matrix spikes.

Percent recoveries of organic matrix samples that were spiked in the laboratory for analysis of NWQL schedule 2080 were more problematic. Recoveries of five target analytes in the sample from Church Creek (12169990) that was spiked at the laboratory with spike mixture for analysis by NWQL schedule 2080 were less than the acceptable criteria: diltiazem, sulfamethoxazole, trimethoprim, diphenhydramine, and thiabendazole. However, Furlong and others (2008) described in their method report that four of the five compounds (with the exception of trimethoprim) had known low percentage recoveries, ranging from 24.3 to 55 percent, in surface water from the South Platte River and recoveries ranging from 22.1 to 88.4 percent in surface water from Boulder Creek that was spiked at similar spike fortifications. The fortification of the spike mix used in the Arlington WWTP sample in 2009 was lower than the fortification of spike mixtures used for the other three spike samples analyzed by NWQL schedule 2080, suggesting that wider range of acceptable recoveries described by Shoemaker and Bassett (2005) may be applicable for this particular sample, but this does not explain all of the lower ranges of recoveries for these WWTP samples. This suggests that the complex matrix of the WWTP samples is causing interference that may result in the poor recoveries. This also implies that results for the environmental may be negatively biased.

Concentration data reported for all constituents include total variation (errors) accumulated through sampling, processing, and analysis. One field replicate from the surface-water reconnaissance sites was submitted to the NWQL for analysis of human pharmaceuticals by NWQL schedule 2080 and three samples from WWTP samples were submitted as replicates for analysis of pharmaceuticals by NWQL custom method 8058 or 8144 . Relative percent differences among pairs of replicate concentrations ranged from zero to 200 percent and the median percent difference for the four replicates ranged from zero to 2.3 percent (appendix table B6).

\section{Quality of Water Data Results}

The analytical results for this study from 2008 through 2011 are contained in tables 2-10. Concentrations of liquid samples are reported in micrograms per liter, except for steroidal hormones and related compounds (table 9), which are reported in nanograms per liter. Concentrations of solid samples are normally reported in micrograms per kilogram of dry solid, but the technique of analyzing solids on filters does not permit determination of the amount of dry solid. The mass of subsequent samples was recorded, and results for the samples were adjusted for volume by dividing the analytical sample result by the volume filtered (in mass). Results were then reported in micrograms per kilogram (table 10). Samples of the first samples collected from the Arlington WWTP are reported only in nanograms. Surrogates are isotope-labeled variants of compounds that are analyzed in particular laboratory schedules or are synthetic compounds normally not found in environmental samples. Surrogates are reported as a percentage of the amount added and are an indicator of the method performance. Oblinger Childress and others (1999) describe method reporting limits used in this report for all parameters.

Tables 2-10 are included as Microsoft ${ }^{\circledR}$ Excel files available for download at http://dx.doi.org/10.3133/ofr20141028.

Table 2. Physical properties in samples from streams in the Stillaguamish River Basin, Washington, September 2008.

Table 3. Concentrations of human-health pharmaceutical compounds analyzed by USGS National Water Quality Laboratory schedule 2080 in samples from streams in the Stillaguamish River Basin, Washington, September 2008.

Table 4. Concentrations of wastewater indicator compounds analyzed by USGS National Water Quality Laboratory schedule 1433 in samples from streams in the Stillaguamish River Basin, Washington, September 2008.

Table 5. Concentrations of pharmaceutical compounds analyzed by USGS National Water Quality Laboratory custom method 8058 in samples from streams in the Stillaguamish River Basin, Washington, September 2008.

Table 6. Physical properties and concentrations of human-health pharmaceutical compounds analyzed by USGS National Water Quality Laboratory schedule 2080 in samples from influent and effluent of wastewater treatment plants in the lower Stillaguamish River Basin, Washington, 2009-11.

Table 7. Concentrations of wastewater indicator compounds analyzed by USGS National Water Quality Laboratory schedule 1433 in samples from influent and effluent of wastewater treatment plants in the Stillaguamish River Basin, Washington, 2009-11. 
Table 8. Concentrations of pharmaceutical and other organic compounds analyzed by USGS National Water Quality Laboratory custom methods 8058 and 8144 in samples from influent and effluent of selected wastewater treatment plants in the lower Stillaguamish River Basin, Washington, 2009-11.

Table 9. Concentrations of steroid hormones and related compounds analyzed by USGS National Water Quality Laboratory custom schedule 2434 in samples from effluent of selected wastewater treatment plants in the lower Stillaguamish River Basin, Washington, September 2010.

Table 10. Concentrations of halogenated organic compounds analyzed by USGS National Water Quality Laboratory custom method 8093 in solids and sediments from selected wastewater treatment plants in the lower Stillaguamish River Basin, Washington, 2009-11.

\section{Acknowledgments}

The authors wish to thank Erik Thornburg and Kelly Wynn (Water and Wastewater Specialties LLC) for assistance in sampling the Warm Beach and Angel of the Winds Casino WWTPs; Mike Wolanek (city of Arlington) for technical assistance in sampling the Arlington WWTP; and Raegan Huffman, C.G. Laird, and Kathy Conn (USGS) for assistance in sampling the Arlington, Warm Beach, and Angel of the Winds Casino WWTPs.

\section{References Cited}

Foreman, W.T., Gray, J.L., ReVello, R.C., Lindley, C.E., Losche, S.A., and Barber, L.B., 2012, Determination of steroid hormones and related compounds in filtered and unfiltered water by solid-phase extraction, derivatization, and gas chromatography with tandem mass spectrometry: U.S. Geological Survey Techniques and Methods, book 5, chap. B9, 118 p., accessed November 28, 2012, at http:// pubs.usgs.gov/tm/5b9/.

Furlong, E.T., Werner, S.L., Anderson, B.D., and Cahill, J.D., 2008, Determination of human-health pharmaceuticals in filtered water by chemically modified styrenedivinylbenzene resin-based solid-phase extraction and highperformance liquid chromatography/mass spectrometry: U.S. Geological Survey Techniques and Methods, book 5, chap. B5, 56 p., accessed April 17, 2012, at http://pubs.usgs. gov/tm/tm5b5/.

Gibs, Jacob, Wilde, F.D., and Heckathorn, H.A., 2007, Use of multiparameter instruments for routine field measurements (ver. 1.1): U.S. Geological Survey Techniques of WaterResources Investigations, book 9, chap. A6, section 6.8, August, accessed September 4, 2013, at http://pubs.water. usgs.gov/twri9A/.
International Union of Pure and Applied Chemistry, 2014, Gold book-matrix effect, in McNaught, A.D., and Wilkinson, A., comps., Compendium of chemical terminology gold book, version 2.3.3 (2d ed.): International Union of Pure and Applied Chemistry Web page, accessed February 23, 2015, at: http://dx.doi.org/10.1351/goldbook. M03759.

Maloney, T.J., ed., 2005, Quality management system, U.S. Geological Survey National Water Quality Laboratory: U.S. Geological Survey Open-File Report 2005-1263, version 1.3, 9 November 2005, chapters and appendixes variously paged, accessed January 22, 2015 at http://pubs.usgs.gov/ of/2005/1263/.

Miller, T.L., 2004, Revised policy for the approval of U.S. Geological Survey (USGS) water-quality analytical methods: U.S. Geological Survey, Office of Water Quality Technical Memorandum 04.01, accessed December 14, 2012, at http://water.usgs.gov/admin/memo/QW/qw04.01. html.

National Atmospheric and Oceanic Administration, 2013, National Weather Service Northwest River Forecast Center: National Atmospheric and Oceanic Administration database, accessed September 5, 2013, at http://www.nwrfc.noaa.gov/ $\mathrm{rfc} /$.

Oblinger Childress, C. J., Foreman, W.T., Connor, B. F., and Maloney, T.J., 1999, New reporting procedures based on long-term method detection levels and some considerations for interpretations of water-quality data provided by the U.S. Geological Survey National Water Quality Laboratory: Open-File Report 99-193, 19 p., accessed March 1, 2015 at http://pubs.er.usgs.gov/publication/ofr99193.

Pait, A.S., and Nelson, J.O., 2002, Endocrine disruption in fish-An assessment of recent research and results, National Oceanic and Atmospheric Administration, 55 p. 
Phillips, P.J., Smith, S.G., Kolpin, D.W., Zaugg, S.D., Buxton, H.T., and Furlong, E.T., 2010, Method description, quality assurance, environmental data, and other information for analysis of pharmaceuticals in wastewater-treatmentplant effluents, streamwater, and reservoirs, 2004-2009: U.S. Geological Survey Open-File Report 2010-1102, 36 p., accessed January 21, 2016, at http://pubs.usgs.gov/ of/2010/1102/.

Shoemaker, J.A., and Bassett M. V., 2005, Method 535Measurement of chloroacetanilide and other acetamide herbicide degradates in drinking water by solid phase extraction and liquid chromatography/tandem mass spectrometry (LC/MS/MS), April 2005: U.S. Environmental Protection Agency, EPA Document EPA/600/R-05/053, accessed October 21, 2015 at http://nepis.epa.gov/Exe/ ZyPURL.cgi?Dockey=P10096IN.txt

U.S. Geological Survey, 2006, Collection of water samples (ver. 2.0): U.S. Geological Survey Techniques of WaterResources Investigations, book 9, chap. A4, September, accessed November 9, 2012, at http://pubs.water.usgs.gov/ twri9A4/.

U.S. Environmental Protection Agency, 1997, Special report on environmental endocrine disruption-An effects assessment and analysis: U.S. Environmental Protection Agency, EPA/630/R-96/012, 111 p., accessed April 17, 2012, at http://www.epa.gov/raf/publications/pdfs/ ENDOCRINE.PDF.

Wagner, R.J., Boulger, R.W., Jr., Oblinger, C.J., and Smith, B.A., 2006, Guidelines and standard procedures for continuous water-quality monitors-Station operation, record computation, and data reporting: U.S. Geological Survey Techniques and Methods 1-D3, 51 p. plus 8 attachments; accessed January 23, 2016, at http://pubs. water.usgs.gov/tm1d3.

Wagner, R.J., Kimbrough, R.A., and Turney, G.L., 2007, Quality-assurance plan for water-quality activities in the U.S. Geological Survey Washington Water Science Center: U.S. Geological Survey Open-File Report 2007-1307, 48 p., accessed October 21, 2015, at http://pubs.usgs.gov/ of/2007/1307/.
Washington State Department of Ecology, 2013, River and stream flow monitoring - Stillaguamish R. nr Silvana: Washington State Department of Ecology Web site, accessed September 5, 2013, at https://fortress.wa.gov/ecy/ wrx/wrx/flows/station.asp?wria $=05$.

Wilde, F.D., ed., variously dated, Field measurements: U.S. Geological Survey Techniques of Water-Resources Investigations, book 9, chap. A6, accessed November 13, 2008, at http://pubs.water.usgs.gov/twri9A6/.

Wozniak, A.L., Bulayeva, N.N., and Watson, C.S., 2005, Xenoestrogens at picomolar to nanomolar concentrations trigger membrane estrogen receptor-alpha-mediated $\mathrm{Ca} 2+$ fluxes and prolactin release in GH3/B6 pituitary tumor cells: Environmental Health Perspectives 113, p. 431-439.

Zaugg, S.D., Phillips, P.J., and Smith, S.G., 2014, Analysis of pharmaceutical and other organic wastewater compounds in filtered and unfiltered water samples by gas chromatography/mass spectrometry: U.S. Geological Survey Open-File Report 2013-1297, 24 p., accessed November 6, 2014, at http://dx.doi.org/10.3133/ ofr20131297.

Zaugg, S.D., Smith, S.G., Schroeder, M.P., Barber, L.B., and Burkhardt, M.R., 2006, Methods of analysis by the U.S. Geological Survey National Water Quality LaboratoryDetermination of wastewater compounds by polystyrenedivinylbenzene solid-phase extraction and capillary-column gas chromatography/mass spectrometry: U.S. Geological Survey Water-Resources Investigations Report 01-4186, 37 p., accessed October 21, 2015, at http://pubs.usgs.gov/ wri/wri014186/. 


\section{Appendix A. Contaminants of Concern for Which Samples Were Collected and Analyzed, Stillaguamish River Basin, Washington, 2008-11}

Appendix A tables A1-A6 are included as Microsoft@ Excel files available for download at http://dx.doi.org/10.3133/ofr20141028.

Table A1. Parameter codes, parameter names, alternative or common names, typical uses, Chemical Abstracts Service (CAS) Registry Numbers, and reporting levels for human-health pharmaceutical compounds analyzed by USGS National Water Quality Laboratory Schedule 2080 for samples from the Stillaguamish River Basin, Washington, 2008-11.

Table A2. Parameter codes, parameter names, alternative or common names, typical uses, Chemical Abstracts Service (CAS) Registry Numbers, and reporting levels for pharmaceutical and other organic compounds analyzed by USGS National Water Quality Laboratory custom methods 8058 and 8144 for samples from the Stillaguamish River Basin, Washington, 2008-11.

Table A3. Parameter codes, parameter names, typical uses or sources, Chemical Abstracts Service (CAS) Registry Numbers, and reporting levels for wastewater indicator compounds analyzed by USGS National Water Quality Laboratory Schedule 1433 in samples from the Stillaguamish River Basin, Washington, 2008-11.

Table A4. Parameter codes, parameter names, typical uses or sources, Chemical Abstracts Service (CAS) Registry Numbers, and reporting levels for steroidal hormones and related compounds analyzed by USGS National Water Quality Laboratory custom method 2434 in samples from the Stillaguamish River Basin, Washington, September 2010.

Table A5. Parameter codes, parameter names, Chemical Abstracts Service (CAS) Registry Numbers, and reporting levels for halogenated organic compounds in solids and sediments analyzed by USGS National Water Quality Laboratory custom method 8093 for samples from the Stillaguamish River Basin, Washington, 2009-11.

Table A6. Types and numbers of environmental samples processed for streams and wastewater treatment plants in the Stillaguamish River Basin, Washington, 2008-11. 


\section{Appendix B. Quality Control Samples Processed from the Stillaguamish River Basin, 2008-11}

Appendix B tables B1-B6 are included as Microsoft@ Excel files available for download at http://dx.doi.org/10.3133/ofr20141028.

Table B1. Types and numbers of quality-control samples processed for streams and wastewater treatment plants in the Stillaguamish River Basin, Washington, 2008-11.

Table B2. Percent recovery of surrogate compounds and concentrations of organic compounds in field blanks processed in the Stillaguamish River Basin, Washington, 2008-11.

Table B3. Field matrix spike recoveries in quality-control samples analyzed by USGS National Water Quality Laboratory schedule 1433 in samples from the Stillaguamish River Basin, Washington, 2008-11.

Table B4. Laboratory matrix spike recoveries in quality-control samples analyzed by USGS National Water Quality Laboratory schedule 2080 and custom schedule 2434 in samples from the Stillaguamish River Basin, Washington, 2009-11.

Table B5. Parameter code, parameter name, and field matrix spike recoveries that are outside the acceptance criteria for qualitycontrol samples of wastewater indicator compounds in samples from the Stillaguamish River basin, 2008-11.

Table B6. Concentrations and relative percent difference in replicates analyzed by National Water Quality Laboratory schedule 2080 and custom methods 8058 and 8144 in samples from the Stillaguamish River Basin, Washington, 2008-11. 
Publishing support provided by the U.S. Geological Survey

Publishing Network, Tacoma Publishing Service Center

For more information concerning the research in this report, contact the Director, Washington Water Science Center

U.S. Geological Survey

934 Broadway, Suite 300

Tacoma, Washington 98402

http://wa.water.usgs.gov 


\section{हू}

$\sum$

产

ํㅡㄹ

웋

$\frac{\pi}{5}$

잉

ํㅗㄹ

言

움

䲞

을.

8

ํㅗำ

三.

㝏

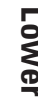

흘

혿.

꼻

प్

$\stackrel{-}{S}$

\ู

兽.

흥

ธิธ

$\stackrel{\vec{l}}{\mathrm{l}}$

응

要

(1)

응

N

点

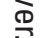

№ 